\title{
СОЦАЛЬНА ПОСЛУГА ЗА БЮДЖЕТНИЙ КОШТ ЯК ЕЛЕМЕНТ ПІДГОТОВКИ СОЦІАЛЬНИХ ПРАЦІВНИКІВ ДО ПРОФЕСІЙНОГО САМОВИЗНАЧЕННЯ
}

\author{
Саранча I. $\Gamma$. \\ кандидат педагогічних наук, \\ доиент кафедри психології та соиіальної роботи \\ Вінницький державний педагогічний університет імені Михайла Кочюбинського \\ вул. Острозького, 32, Вінниия, Україна \\ orcid.org/0000-0002-5715-6271 \\ anika.line@gmail.com
}

\author{
Ключові слова: підготовка \\ спецііаліста, соиіальний \\ працівник, професійне \\ самовизначення, сочіальна \\ послуга за бюджетний кошт, \\ співпрацяя.
}

\begin{abstract}
Пропонований науковий огляд стосується питань підготовки спеціалістів соціальної та освітньої сфер. Зокрема, це стосується питання підготовки соціальних працівників, що має відбуватися в умовах зміни підходів до надання послуг, анонсованих державою. Так, окремо розкривається питання передачі повноважень органів виконавчої влади 3 числа надавачів послуг недержавним організаціям, об'єднанням громадян та приватним особам для здійснення обслуговування населення певної територіальної громади на засадах доступності та відкритості через механізм реалізації соціальної послуги за бюджетний кошт. Основна увага приділяється питанню використання пропонованого державою механізму для практичної підготовки студентської молоді до професійного самовизначення. Оскільки основне завдання вищої освіти - підготувати компетентного фахівця в певній сфері, ми розглядаємо дане питання в рамках психолого-педагогічної, психологічної, соціально-педагогічної та/чи соціально-реабілітаційної практики, а також у межах волонтерської діяльності в позанавчальному процесі. Так, через включення в процеси надання соціальних послуг за бюджетний кошт та в рамках співпраці вищих навчальних закладів із громадськими організаціями відбувається якісна підготовка спеціалістів. У таких умовах соціальний працівник, майбутній соціальний педагог, фахівець із соціальної роботи тощо знайомляться безпосередньо з практикою використання набутих знань під час надання послуг населенню відповідно до державних стандартів і включаються в усі процеси роботи - від ведення документації, розуміння супутніх юридичних питань, соціально-економічного та соціокультурного ефекту, співпраці з відповідними органами виконавчої влади, комунальними закладами та іншими установами і до питання власне алгоритму співпраці 3 отримувачами послуг. Усе це сприяє глибокому розумінню майбутнім фахівцем власних можливостей та відповідальності, які належатимуть до його компетенції у разі вибору того чи іншого професійного напряму: власне роботи в закладах освіти, соціальних установах чи громадських організаціях.
\end{abstract}




\title{
PUBLICLY-FUNDED SOCIAL SERVICES AS AN ELEMENT OF TRAINING A SOCIAL PEDAGOGUE TO PROFESSIONAL SELF-DETERMINATION
}

\author{
Sarancha I. G. \\ Candidate of Pedagogical Sciences, \\ Associate Professor at the Department of Psychology and Social Work \\ Vinnytsia Mykhailo Kotsiubynskyi State Pedagogical University \\ Ostrozkogo str., 32, Vinnytsia, Ukraine \\ orcid.org/0000-0002-5715-6271 \\ anika.line@gmail.com
}

Key words: specialist training, social pedagogue, professional self-determination, publiclyfunded social services, collaboration.

\begin{abstract}
The scientific review concerns the training of specialists in social and educational sector. In particular, it concerns the training of social pedagogues, which must take place under conditions of changing approaches to the provision of services announced by the state. Thus, a separate disclosure is made of the transfer of powers of the governing bodies from service providers to non-state organizations, associations of citizens and private individuals to provide public services to the selected territorial community on the basis of accessibility and openness through the mechanism of realization of social services at public expense. The main attention is paid to the use of the state-promoted mechanism for the practical training of students to professional self-recognition. Since the main aim of higher education is to prepare a competent specialist in a particular area, we consider this issue within the framework of psychological and pedagogical, psychological, social and / or social rehabilitation practices, as well as within the framework of volunteer activities in the extracurricular process. Thus, through involvement in the provision of social services at public expense and through cooperation between higher education institutions and community organizations, quality training of specialists is ensured. After all, under such conditions, the social worker or future social pedagogue, social work specialist, etc., is introduced directly to the practice of using the acquired knowledge in providing services to the population in accordance with state standards and is included in all work processes (documentation procedures; related juridical issues; socio-economic and socio-cultural impact; cooperation with relevant regulatory authorities, utilities and other institutions; algorithm of interaction with recipients of services). All this contributes to a thorough understanding by the future practitioner of the own possibilities and responsibilities that belong to his/her competence in case of choosing one or another professional field - own work in educational institutions, social institutions or public organizations.
\end{abstract}

Постановка проблеми. Сьогодні в Україні питаннями надання соціальних послуг населенню займаються, відповідно до Закону України «Про соціальні послуги», надавачі соціальних послуг (юридичні та фізичні особи, фізичні особи - підприємці, включені до розділу «Надавачі соціальних послуг»), серед яких також є працівники системи надання соціальних послуг чи їх об'єднання [1]. Ураховуючи останні зміни в пріоритетах державної соціальної політики, що посилила реформа децентралізації влади, окремі послуги було запропоновано передати громадським організаціям чи відповідальним надавачам на підставі соціального замовлення, що формується відповідно до пріоритетів громади та здійснюється за бюджетні кошти [5].

Такий підхід забезпечив сприятливі умови не лише для громади, отримувачів послуг, а також для закладів освіти, що забезпечують професійну підготовку та формування майбутніх фахівців соціальної сфери. Саме тому, на нашу думку, важливо розглянути питання впливу соціальної послуги за бюджетний кошт на процес підготовки соціального працівника та його професійне самовизначення, адже практика $\epsilon$ необхідним елементом підготовки якісного фахівця та його вибору подальшого напряму професійної активності. 
Аналіз останніх досліджень і публікацій. Так, iз педагогічного погляду до питання підготовки i професійного самовизначення майбутніх фахівців у вищих навчальних закладах звертаються у своїх наукових пошуках: А. Попович («Модернізація підготовки соціальних працівників у контексті дуальної освіти»), І. Бодрова та Н. Чернуха («Професійне самовизначення майбутніх соціальних працівників у сучасних українських умовах як соціально педагогічна проблема»), Є. Кісілюк («Професійне самовизначення особистості на етапі підготовки у здобувачів вищої освіти») та ін. Із правового та економічного погляду можна відзначити, що дане питання частково охоплюють Н. Майка («Правове регулювання соціального замовлення»), Б. Малиняк та М. Онуфрик («Придбання соціальних послуг органами місцевого самоврядування у приватних суб'єктів: проблеми адміністрування та фінансування») тощо, але узагальнюючих досліджень щодо соціального, економічного ефектів та професійної підготовки (самовизначення майбутнього спеціаліста) немає.

Водночас нами було окреслено досвід роботи 3 організації соціально-педагогічної діяльності студентської молоді, зокрема спеціальності «Педагог соціальний» та спеціалізації «Соціальна робота», в межах реалізації соціальних проєктів, що презентовано в попередній публікації [11]. Під час пропонованої практики студенти долучалися до роботи громадських організацій, які надавали послуги населенню відповідно до своїх статутів та за грантові кошти державних структур чи міжнародних донорів, що дало їм змогу безпосередньо в процесі роботи побачити особливості надання послуг у закладі освіти, у державних установах та на базі громадських організацій чи соціальних установ, порівняти умови праці, юридичну та фінансову відповідальність, а також на основі отриманого практичного досвіду здійснити вибір пріоритетного для себе напряму майбутньої професійної самореалізації.

Постановка завдання. На основі власного досвіду впровадження соціальної послуги за бюджетний кошт та аналізу науково-педагогічних робіт наших колег щодо підготовки соціальних педагогів та соціальних працівників нами було визначено мету даного наукового огляду - розкрити основні положення питання професійного самовизначення та його взаємозв'язок з упровадженням такої послуги у практику викладання у ВНЗ.

Виклад основного матеріалу дослідження. Досліджуючи питання професійного самовизначення та його законодавчого обгрунтування, ми звернулися до спільного наказу двох міністерств, що окреслював професійне самовизначення як «самопізнання та об'єктивну самооцінку індивідуальних особливостей, співставлення своїх професійно важливих якостей і можливостей із вимогами, необхідними для набуття конкретних професій, та кон'юнктурою ринку праці», що, своєю чергою, є невід'ємною частиною професійної орієнтації [7]. Відповідно до закону, робота 3 професійного самовизначення має два етапи:

- допрофесійний, що включає курс «Вибір професії» і вивчається у 9-х класах загальноосвітніх шкіл, результатом якого мають бути «сформованість особистісно значимого смислу вибору професії, певної професійної спрямованості (професійних намірів, планів оволодіння професією, професійної перспективи), професійне самовизначення учнів, готовність до зміни професійної спрямованості та переорієнтації на суміжні професії, інші види діяльності відповідно до індивідуальних особливостей учнів та результатів профвідбору»;

- професійний, що передбачає «оволодіння професійними знаннями, уміннями, навичками; адаптацію до професійного навчально-виховного закладу і нового соціального статусу; формування професійної мобільності, готовності до продовження професійної освіти і самовдосконалення, розвиток професійних інтересів і професійно важливих якостей; уточнення подальшої професійної перспективи». У результаті особистість має набути компетентностей, які забезпечать ії конкурентоспроможність на ринку праці та готовість до активної професійної діяльності, а за потреби і «переорієнтації на певну професію» [7].

Варто відзначити, що навіть сьогодні, як зазначає В. Кузьмін, більшість студентської молоді керується кар'єрними архетипами, що за своєю суттю $є$ «безпосередніми продуктами соціалізації i формуються у родині, школі, внаслідок первинної профорієнтації та орієнтації на соціально-культурні зразки поведінки, продуковані засобами масової інформації та продуктами масової культури» $[4$, с. 60$]$. Це не лише призводить до стереотипізації окремих «міфів про професію», а й заважає на етапі включення у професійну діяльність, оскільки «догматично» засвоєний образ під час профорієнтаційної роботи часто не відповідає реаліям тієї професійної активності та її економічного ефекту, які майбутній фахівець матиме на виході. Важливим у цьому аспекті, на нашу думку, також $€$ розуміння та пріоритети ціннісного ставлення особистості до майбутньої професійної діяльності, адже вибір часто асоціюється з такими питаннями, як цікава робота, гарантія відсутності втратити роботу (іі стабільність), хороший колектив, зручний режим роботи, можливість спілкуватися 3 людьми та набувати нових навичок, власне відповідність вимогам на роботі здібностям і можливостям особистості, рівність учасників робочого процесу, можливість проявляти ініціативу та відкритість кар'єрного зростання тощо [9, с. 152-153]. 
Таким чином, другий етап стає невід'ємною частиною «розвіювання міфів» та власне навчального процесу у вищих навчальних закладах, де підготовка має здійснюватися як у форматі аудиторної та самостійної роботи, так і під час практики різного спрямування. Саме під час практики студент спостерігає за реальною роботою фахівців, у нашому разі соціальної сфери, і чим більше закладів, що надають соціальні послуги, відвідає майбутній спеціаліст, тим більше шансів віднайти саме той профіль роботи, який буде йому до снаги і до душі.

Таким чином, у підготовці спеціаліста, який має можливості реалізувати себе як фахівець сфери освіти, соціальних структур чи громадського сектору важливим є розуміння власне соціальних послуг, їх різновидів та спрямованості. Відповідно до Закону України, на практиці соціальний працівник, який вибирає сферу освіти, має забезпечити виконання послуги соціальної профілактики із запобігання виникненню складних життєвих обставин та/або потраплянню особи/ сім'ї в такі обставини [1]. Окрім того, такий фахівець може бути частиною команди психолого-педагогічного супроводу як залучений спеціаліст від закладу освіти (особливо якщо йдеться про життя та здоров'я дитини шкільного віку), і тоді обсяг обов'язків та повноважень розширюється до надання соціальної підтримки для сприяння подоланню особою/сім'єю складних життєвих обставин. Усі ці послуги є частиною комплексної соціальної послуги, що передбачають узгоджені дії фахівців із надання постійної або систематичної комплексної допомоги та головне - забезпечують виховання, соціальну адаптацію та соціальну інтеграцію дитини [1].

Саме такий обсяг завдань, що має охопити педагог соціальний чи соціальний працівник, створює специфічні вимоги до процесу підготовки фахівця, i, на нашу думку, саме використання нововведень із надання соціальних послуг за державний кошт може сприяти розширенню практичної частини підготовки у вищих навчальних закладах.

Варто відзначити, що соціальне замовлення відбувається на основі діючих державних стандартів надання соціальних послуг і має на меті «полегшити» навантаження на соціальні структури державної форми власності, оскільки їх матеріально-технічне та кадрове забезпечення не завжди відповідає «нормі». Окрім того, через складність та високе навантаження на спеціалістів, що зумовлені вмінням працювати в умовах розуміння особистості отримувача послуг, неповторності його життєвої ситуації та необхідності постійного пошуку різноманітності засобів здійснення соціальної роботи та надання відповідних послуг [2, с. 112], спостерігається висока плин- ність кадрів та професійне вигорання діючих спеціалістів, адже надання таких послуг незалежно від місця роботи фахівця (школа, центр соціальних служб, громадська організація, кризовий центр тощо) «представляє єдність соціально-психологічної й соціально-педагогічної допомоги, соціокультурної діяльності, соціально-економічної і правової підтримки [2, с. 112].

Серед чинних державних стандартів, 3 якими мають бути обізнані всі соціальні працівники, зокрема соціальні педагоги, такі: Державний стандарт денного догляду; Державний стандарт соціального супроводу сімей (осіб), які перебувають у складних життєвих обставинах; Державний стандарт соціального супроводу сімей, у яких виховуються діти-сироти і діти, позбавлені батьківського піклування; Державний стандарт соціальної адаптації; Державний стандарт соціальної послуги консультування; Державний стандарт соціальної послуги кризового та екстреного втручання; Державний стандарт соціальної послуги посередництва (медіації); Державний стандарт соціальної послуги представництва інтересів; Державний стандарт соціальної послуги профілактики; Державний стандарт соціальної послуги соціальної інтеграції випускників інтернатних закладів (установ); Державний стандарт соціальної реабілітації осіб з інтелектуальними та психічним розладами; Стандарти надання соціальних послуг особам, які постраждали від торгівлі людьми.

Таким чином, звертаючись до потреби включення практики роботи в різних умовах для формування світогляду та формування якісних уявлень про форми роботи соціального працівника в закладах освіти, соціального захисту чи громадських об'єднаннях, ми вважаємо актуальним вивчення і залучення закладів вищої освіти до отримання соціального замовлення від територіальної громади. Загалом сьогодні й сам заклад освіти має можливість спланувати відповідну діяльність за допомогою типового плану специфікації, дотримуючись такої послідовності в описі пропонованої соціальної послуги за бюджетний кошт територіальної громади:

- чинна нормативна база, що окреслює законність надання такої послуги та підстави для надання ii не державними структурами, а залученими спеціалістами, а також залежно від категорії отримувачів послуг;

- визначення потреби у залученні таких спеціалістів виходячи зі статистичних даних та звітів територіальної громади;

- визначення категорії отримувачів та їхньої кількості;

- визначення самої послуги відповідно до державних стандартів, їх характеру, якості та кількості; 
- визначення учасника конкурсу, тобто структури, яка пропонуватиме надання даної послуги, оскільки власне навчальний заклад не має сьогодні юридичних повноважень до надання такої послуги, що створює умови для налагодження співпраці 3 громадськими організаціями чи іншими стейкхолдерами;

- власне соціальна чи соціально-освітня конкурсна пропозиція, що містить презентацію, опис пропозиції, окремий опис основних характеристик відповідно до стандартів звітування (методика оцінювання ефективності, гарантії ефективності послуги, фінансові документи тощо);

- персонал (кількість, його кваліфікація та графік роботи);

- матеріально-технічне забезпечення та архітектурне планування;

- фінансові дані установи, що подає пропозицію;

- оцінювання діяльності та партнерство.

Звичайно, заклади можуть, але не мають виступати в ролі основних отримувачів бюджетних коштів. Зазвичай це якісний симбіоз із громадськими організаціями, які передають частину повноважень у рамках договорів про співпрацю, залишаючи за собою право скеровувати процеси надання послуг, час та місце, форму проведення роботи (групова чи індивідуальна), а також проводити спільно 3 відповідальним за практику викладачем супервізію за результатами роботи студентів.

Форми організації такої співпраці багато в чому залежать від того, як працюють соціальні служби освіти, громади чи підприємств, вирішуючи основні «завдання реалізації соціальних функцій, здійснюючи аналіз, облік і використання ресурсів» учасників процесу, звертаючись до їхнього соціального самовизначення й адаптації до професійної діяльності в заданих умовах [3, с. 123]. Так, серед найбільш часто використовуваних практик залучення студентської молоді до професійної активності можна відзначити:

- сприяння волонтерській та культурнодозвіллєвій діяльності (організації та проведення заходів, акцій, реалізація програм і проєктів тощо);
- стимулювання самоосвіти та саморозвитку (участь у тренінгах, майстер-класах, семінарах, опрацювання додаткової літератури);

- залучення до реалізації державних програм соціально-економічного та культурного розвитку через співпрацю з громадою та державними органами влади, які їх реалізують;

- виконання соціального замовлення місцевого самоврядування через співпрацю 3 громадськими організаціями;

- реалізацію проєктних пропозицій, що пройшли конкурсний відбір фінансування місцевою громадою [6, с. 361-362; 11, с. 127].

Такий підхід до організації освітнього процесу iз залученням до щоденної практики реалізації соціальних послуг дає змогу ефективно комунікувати 3 надавачами послуг (стейкхолдерами) та отримувачами послуг; зануритися в «атмосферу» практичної роботи та іiі документального супроводу. I, що досить важливо, розширити коло компетентностей майбутнього спеціаліста знаннями методичного та юридичного складників у процесі надання освітніх, соціальних чи соціально-педагогічних послуг для досягнення мети та ефективної комунікації $[8$, с. 156]. А це, своєю чергою, $є$ особливою здатністю особистості до рефлексії, емоційної стійкості, самостійності в прийнятті рішень і вчинків, а також частиною того позитивного досвіду долати життєві проблеми, приймати відповідальні рішення та здійснювати вмотивовані вчинки в реальних життєвих ситуаціях [10, с. 186], що сприяє ефективній професійній діяльності в майбутньому, адже особистість, яка не має практичного досвіду подолання труднощів та швидкої адаптації до змін, не має необхідних знань та навичок, щоб допомагати іншим.

Висновки 3 проведеного дослідження. Пропонований огляд не може претендувати на повноцінну оцінку ефективності впровадження у практику роботи ВНЗ методів підготовки спеціалістів на основі соціальної послуги за державний кошт, але окреслює основні тенденції залучення студентської молоді, яка отримує освіту як соціальний працівник чи соціальний педагог, до вивчення сутності професії та подальшого самовизначення майбутнього фахівця.

\section{ЛІТЕРАТУРА}

1. Закон України «Про соціальні послуги» № 2671-VIII від 17 січня 2019 p.

2. Копилова С.В. Особливості соціальної роботи як професії. Габітус. 2016. Вип. 1. С. 108-112.

3. Кубіцький С.О. Технології соціально-педагогічної роботи в зарубіжних країнах : навчальний посібник. Київ : Міленіум, 2015. 300 с.

4. Кузьмін В. «Ситуація ножиць» як інституційна пастка реалізації кар'єрних стратегій в Україні: чинники появи та шляхи подолання. Украӥнський соџіологічний журнал. 2019. № 19(1-2). С. 58-63.

5. Постанова КМУ «Про затвердження Порядку установлення диференційованої плати за надання соціальних послуг» № 429 від 01.06.2020.

6. Слозанська Г.І. Теорія і практика підготовки майбутніх соціальних працівників до роботи у територіальних громадах. 2019. 
7. Спільний Наказ МОН, Мінпраці, Мінсім'їмолодьспорту України «Про затвердження Положення про професійну орієнтацію молоді, яка навчається) № 159/30/1526 від 02.06.1995.

8. Хіля А.В., Саранча І.Г. Компетентнісний підхід у професійній підготовці вчителів та спеціалістів інклюзивного освітнього простору. Молодий вчений. 2018. № 5.2(57.2). С. 155-158.

9. Филинская Л. Работа как ценность: из недалекого прошлого в ближайшее будущее. Украӥнський соиіологічний журнал. № 17(1-2). С. 150-160.

10. Шинкар М.І. Психологічна готовність студентської молоді до асертивної поведінки. Габітус. 2020. Вип. 13. Т. 1. С. 184-188.

11. Sarancha I.H., Khilya A.V. Socio-educational activity of students in the framework of social projects. Ukr. Socium. 2020. № 4(75). C. 125-135.

1. Zakon Ukrainy (2019) №2671-VIII.

\section{REFERENCES}

2. Kopylova S.V. (2016) Specificity of social work as a profession. Habitus. V.1. 108-112.

3. Kubitskyi S.O. (2015) Tekhnolohii sotsialno-pedahohichnoi roboty v zarubizhnykh krainakh [Technologies of socio-pedagogical work in foreign countries]. Kyiv: Milenium.

4. Kuzmin V. (2019) The «scissors situation» as an institutional trap for the implementation of career strategies in Ukraine: factors of emergence and ways to overcome them. Ukrainskyi sotsiolohichnyi zhurnal. 19(1-2). 58-63.

5. Postanova KMU (2020) №429

6. Slozanska H. (2019) Theory and practice of future social workers training for the work in territorial communities. Manuscript. Ternopil: Ternopil Volodymyr Hnatiuk National Pedagogical University.

7. Spilnyi nakaz MON, Minpratsi, Minsimiamolodsport Ukrainy (1995) №159/30/1526

8. Khilya A.V., Sarancha I.G. (2018) Competently approach to professional training of teachers and specialists in space for inclusive educational. Young Scientist. №5.2 (57.2). 155-158.

9. Filinskaya L. (2015) Rabota kak cennost': iz nedalekogo proshlogo v blizhajshee budushhee [Work as a value: from the not-too-distant past to the near future]. Ukrainskyi sotsiolohichnyi zhurnal, 17(1-2), 150-160.

10. Shynkar M.I. (2020) Psychological readyness of student youth for assertive behavior. Habitus. V.13. T.1. 184-188.

11. Sarancha I.H., Khilya A.V. (2020) Socio-educational activity of students in the framework of social projects. Ukr. socium. 4(75). 125-135. 